\title{
The Relationship between ReflectiveTeaching, Willingness to Communicate (WTC), and Intrinsic Motivation of Iranian Advanced Learners
}

\author{
Mohammad Zohrabi \\ English Department \\ Faculty of Persian Literature and Foreign Languages \\ University of Tabriz, Tabriz, Iran \\ Maryam Yousefi \\ Aras International Campus \\ University of Tabriz, Tabriz, Iran
}

\begin{abstract}
The present study aimed at examining the relationship between reflective teaching, willingness to communicate (WTC), intrinsic motivation and language proficiency of Iranian EFL learners. To address the objectives of the study a correlational and a quasi-experimental design were adopted. As for the correlational phase of the study, initially 20 teachers and 240 EFL advanced learners were identified. Then, the questionnaires were distributed among them. The reflective teaching questionnaire was distributed among the teachers and the WTC along with the intrinsic motivation questionnaires were given to the learners to be filled out. In order to obtain the proficiency scores of the participants, a TOEFL was administered to the 240 advanced learners. As for the experimental phase of the study, initially, two teachers, a reflective teacher and a non-reflective teacher, were selected based on the results of reflective teaching questionnaire. Following that, 60 participants who had been chosen based on the normal curve and standard deviation were divided randomly into two groups, i.e. an experimental and a control group. The experimental group was taught by the reflective teacher. No tangible reflective actions were adopted by the teacher in this group. Finally, both groups sat for the PET exam the results of which were used to explore the impact of reflective teaching on the proficiency level of the participants. The results of data analysis indicated that there was a significantly positive relationship between reflective teaching, willingness to communicate and intrinsic motivation as well as proficiency test scores of the participants.
\end{abstract}

Keywords: willingness to communicate, reflective teaching, intrinsic motivation.

\section{INTRODUCTION}

Reflective teaching takes account of the thoughtful nature of teachers' work. Aiming at shedding light on reflective teaching, studies on teacher training have provided evidence supporting the contributions of such a type of teaching. Attention now is on the way teachers think about their job. Reflective practice was characterized by Farrell (1999) as a practice which can provide the teachers with an opportunity to put their tentative ideas concerning teaching to test for the purpose of making their teaching practice more effective. In this study we tried to find answer to the following research questions:

Q1: Is there any significant relationship between reflective teaching and Willingness to Communicate?

H0: There is no significant relationship between reflective teaching and Willingness to Communicate.

AH: There is a significant relationship between reflective teaching and Willingness to Communicate.

Q2: Is there any significant relationship between reflective teaching and intrinsic motivation?

H0: There is no significant relationship between reflective teaching and intrinsic motivation.

$\mathrm{AH}$ : There is a significant relationship between reflective teaching and intrinsic motivation. 


\section{REVIEW OF THE RELATED LITERATURE}

\subsection{Speaking in a Foreign Language}

Bygate (1987) believes that speaking skill is associated with two branches of motor-perceptive skill and interaction skills. The former is about the sound and structure of the language and the latter belongs to linguistic choices to communicate successfully.

A review of the literature on speaking shows two main approaches to defining this construct: 1- topdown approach 2- bottom-up approach. Elaborating on bottom-up position, Bygate (1987) asserts that the traditional approach to speaking defined speaking as the utterance of auditory signals to produce differential verbal reactions in the listener. Accordingly, it put emphasis on motor perceptive skills. In the same veins, speaking was considered as putting together sounds systematically to yield meaningful utterances by drawing on principles specific to language. Audio-lingualism made extensive use of this approach. As for teaching speaking, the bottom-up approach insists on beginning with the smallest unit-sounds and going on with mastery of vocabulary and eventually discourse (Cornbleet \& Carter, 2001).

As a matter of fact, the main downside of this approach is that it turns a blind eye on the interactions and social aspects involved in speaking, confining speaking only to its psychomotor aspects. In addition, working with this approach, teachers cannot make sure that learners will apply what they have learned in the classroom to the outside real life situation. To address this shortcoming, Bygate (1998) supported using a definition of speaking in terms of the social and interaction skills used for engaging in communication. This approach to speaking is called top-down speaking. Drawing on this approach, Eckard and Kearny (1981) as well as Florez (1999) characterized speaking as a mutual process in which ideas, information, and emotions are communicated. According to this approach, as a result of cooperation between two or more speakers who share the time and physical context, the spoken texts are produced. The advocates of top-down approach assert that from the outset, learners should be encouraged to engage in spoken discourse instead of teaching them how to utter correct sentences. "Thanks to this approach, the learners will gradually pick up the smaller units and then longer units" (Nunan, 1989, p. 32).

\subsection{Teaching Speaking}

The successful key of teaching in speaking skill "is the way teachers organize and respond to students' work" (Harmer, 1983, p. 275). According to Kasper (2001), within the context of foreign language learning, learners can only practice speaking what they feel comfortable in the classroom and have limited access to real-life conversations.The solution is the use of tasks which is in keeping with the hypotheses accounting for acquisition of foreign language. For example, Output hypotheses put forward by Swain (1985) maintains that tasks use can develop second language in both FL and SL. Swain asserted that learners can test their own language-related hypotheses by producing language (output). As a result of this process, they can gain control over the language and internalize the linguistic knowledge. Consequently, the production of output in tasks is a derivative of the language learning process; instead it is considered a step in the process (Adams, 2003).

Another theoretical development providing rationale for making use of tasks in foreign language classrooms was "interaction hypothesis" proposed by Long (1996). Achieving mutual comprehension through negotiation of meaning is the main theme raised by this hypothesis. Attempts to gain mutual comprehension entails the application of many strategies including demanding the speaker to confirm the content of the message or asking him/her to give more clarifications. This type of negotiation is claimed to enhance L2/FL knowledge. In the same veins, tasks are assumed to provide the learners with an opportunity to engage with discourse, improving their communicative competence (Ellis, 2003; McCarthy \& Carter, 2001).

Another theory supporting the application of tasks for learning how to communicate is socio-cultural theory proposed by Vygotsky. This theory holds that tasks develop internally by learners being engaged in the verbal interaction contextualized in the performance of the tasks, leading to the facilitation of language acquisition.

\subsection{Advantages of using Tasks in Teaching Speaking}

Essentially, communicative tasks are conducted by the learners in order to figure out the meaning of those aspects of communicative tasks that are unfamiliar as well as to establish the procedures 
required for accomplishing task goals. This will enhance the acquisition of language (Courtney, 1996; Finch, 1999 \& Lee, 2000).

The studies conducted by Ur (1996) show that the extent to which learners talk in a limited timeframe of the classroom increases through engaging in group work and pair activities. In addition, these activities decrease students' unwillingness to talk as they become more motivated to speak. Moreover, due to their diversity, tasks including role plays and drama can provide the learners with chances to participate in various speech events and communicative contexts. These tasks give the learners chances to rehearse an extensive set of sociolinguistic skills learners need to use in situations outside the classroom (Kasper, 2001; Ellis, 2003). In addition, learners' discourse competence will improve as their skills at producing coherent, fluent flows of speech will enhance through participating in the tasks (Sayer, 2005; Slimani-Rolls, 2005).

\subsection{Willingness to Communicate}

Burgoon (1976, p. 60) defined the unwillingness to communicate construct as a global communication construct that represents the predisposition of "a chronic tendency to avoid and/or devalue oral communication". Burgoon (1976) considered two factors including approach-avoidance and reward, respectively, to determine the tendency a person has to participate in communication and whether an individual believes that the communication is rewarding or not.

The concept of WTC was first introduced by McCroskey and Richmond in 1985 while the effectiveness of WTC in the field of second language learning was proposed by MacIntyre et al. (1998). They believe that WTC is something that is related and limited to certain occasions and situations rather than being a characteristic (MacIntyre et al., 1998).

Grounded in the studies of Philips on reticence $(1965,1968)$, the ongoing construct of willingness to communicate has come out from the endeavors of Burgoon (1976) on the concept of unwillingness to communicate and also from Mortensen et al. (1977) efforts on predispositions toward behavior as well as McCroskey and Richmonds' (1982) and the concept chiefly has its focus on the construct of shyness.

Three main avenues of research gave rise to WTC (Matsuoka \& Evans, 2005). They are unwillingness to communicate (Burgoon, 1976); predisposition toward verbal behavior (Mortenson, Arntson, \&Lustig, 1977; as cited in McCroskey\& Baer, 1985); and shyness (McCroskey\& Richmond, 1982). All ofthese researcheshad one outstanding weakness which was the inability to operationalize what they had postulated (McCroskey\& Baer, 1985).

In the literature, two orientations toward the study in the field of WTC can be observed. The first orientation focuses more on a trait-like predisposition for WTC; although, later studies focuses more on the situational construct for WTC (Kang, 2005); nevertheless, WTC is considered as being adual characteristic construct (Cao \&Philp, 2006), namely trait-like WTC and situational WTC, and they should be assumed as complementary and studied together (MacIntyre, Babin, \& Clement, 1999).

Mortensen et al.'s (1977) research advanced the investigation of predisposition feature of communication behavior one step further. The researchers found that the amount of communication for an individual across various communication settings was consistent. Hence, they named this consistency predisposition toward verbal behavior. They developed the predisposition toward the verbal behavior scale and employed the scale to evaluate the global predisposition characteristics.

The third work concerning the conceptualization of initial concept of WTC was McCroskey and Richmond's (1982) research on shyness. Leary (1983) suggested that shyness is a construct named social anxiety that is formed of internally experienced discomfort and externally observable behavior.

McCroskey and Richmond defined shyness as "the tendency to be timid, reserved, and most specifically, talk less" (p. 460). This shyness scale was employed to quantify the amount of talk, which individuals in average are engaged in. The results of the research indicated that the shyness measurement scale can be assumed as a valid predictor of the communication behavior as far as the amount of talk is considered.

Gender and age are two variables that have been concluded to have an effect on WTC. MacIntyre, Baker, Clement, and Donovan (2002) investigated the influence of age and gender on WTC and other 
variables such as apprehension, perceived competence, and L2 motivation among junior high school L2 French immersion students in a Canada. 268 students, including 96 males and 188 females from grades 7 to 9 aged between 11 and 16, took part in the study. The results from the self-report data showed obvious variations in each variable across the grade levels, and variances based on gender were considerable in WTC and communication apprehension. The students' L2 WTC, perceived competence, and the frequency of communication in French rose from grades 7 to 8 and stayed stable between grades 8 and 9; however, L2 motivation between grades 7 and 8 reduced and the students' communication apprehension level stayed stable across the three grades.

Clement and MacIntyre (2003) believe that WTC in a second language was influenced by the interaction between L2 confidence and L2 norms within the context of intergroup communication. Hence, in conditions where a proficient learner is unwilling to communicate, high motivation for learning and high anxiety about communicating may appear to have a direct influence on L2 use (MacIntyre, 2007).

In another study, MacIntyre et al. (2001) examined the role of social support and language learning orientations on students' WTC in a second language. The results show that social support particularly from friends can significantly influence WTC outside the classroom but it plays less important role in the classroom context.

\subsection{Reflective Teaching}

In recent years, educators have devoted a great deal of their attention to the notion of reflection and the expansion of reflective practice. The idea of reflective teaching was first initiated by Dewey (1933) who believed that, "teachers are not just passive curriculum implementers, but they can also play an active role in curriculum design and educational reform" (p. 49). He suggested that teaching needs to be a process comprising the following components: Hypothesizing, investigation, reasoning, testing and evaluation.

Reflective action, in fact is, "the dynamic, continuous and in-depth consideration of any belief or any form of expertise and knowledge by drawing on the grounds that reinforce it (Dewey, 1933, p. 9, cited in Jay \& Johnson, 2002, p. 74).

These components will lead to adaptations and modification, if needed, leading to a teaching method which will take account of the class dynamics. This is what today has come to be named "reflective teaching".

Bartlett (1990) also defined reflective teaching as follows: reflection points to a practice in which the individual recalls, considers, and evaluates an experience often in relation to a broader purpose. In fact, reflection is a response to the past experiences and is to do with conscious recall and examination of the experience as a foundation for evaluation and decision-making, and as a basis for planning and action.

Ma et al. (2011) proposes that reflective teaching can be seen as a process that can facilitate teaching, learning and understanding and which plays a key role in the professional development a teacher. The importance of reflective teaching is well elaborated by many scholars. Reflective teaching has the helps make teachers more initiative and responsible in following the practical rationality by the means of examining teaching and learning activities, taking more intelligent actions and forming a deeper understanding of teaching, which eventually help their professional knowledge and ability.

Wallace (1996) argues that "teachers occasionally get engaged in informally evaluating different angles of their professional knowledge"(p. 292). He calls this type of thinking about one's teaching as "informal reflection" (p. 13).

The significance of continuous and professional development of language teachers has been emphasized by many authors in second language teaching. Some researchers have recommended engagement in organized activities as a tool for increasing reflective practice. For example, Parrott (1993) argues that to make room for reflection, it's better to make use of tasks which teachers can work on collaboratively.

Parrott appears to draw on the reflective model of Wallace (1991), though Wallace emphasizes more on the training of pre-service teachers, while Parrott has his attention more on professional growth of serving teachers. He makes a point that developing professional competence entails teachers examining their own assumptions regarding the nature of language and of learning and teaching. 
Much like Parrott, Wajnryb (1992) considers the use of observation tasks as a means to improve professional development. Wajnryb concentrates on the notion of "the reflective practitioner" used by Schon (1983) in relation to teaching. A reflective teacher, according to him, is as a person who finds more facts in regard to their own teaching by attempting to evaluating the processes of teaching and learning in their own and others' classrooms.

According to Choy (2012, p.169), "teacher reflection can be thought of as taking necessary steps to analyze and articulate problems before taking action". This makes it possible for more constructive action to taken rather than applying a fast solution (Boody, 2008). The challenge is to have the ability show in action what is taught in the classroom. Many teachers are unable to link their teaching to what they are actually practicing and vice versa (Rudd, et al., 2000).

\subsection{Models/Frameworks of Reflection and Reflective Teaching}

A review of literature on the models of reflection and reflective teaching shows a variety of models. Below, some of these models and frameworks will be discussed. Zeichner and Liston (1996) put forward a reflection model which consists of reflection stages rather than reflection content. This model includes the following 5 dimensions: 1) Fast reflection that is usually personal and private. In this kind of reflection, teachers engage in reflective practices quickly and automatically as they are doing an act. 2) repair that "is considered as reflection-in-action, but in this case, the individual experiences a quick pause for thought," 3) review that "is interpersonal and can occur at any time in or after the teacher's work day," 4) research during which "the teachers' thoughts and observation grow more systematically and deeply centered on particular issues. Stanley (1998) presented a framework entitled 'framework for teachers' with five stages. In stage one, which he called, 'engaging with reflection,' Stanley expounds on teachers' awareness of reflection, pointing out that "When basic personal, professional, and contextual factors are stable and teachers are curious about learning the process of reflecting on their teaching, they can engage with reflection" (p. 686).

To Stanley (1998), such an experience should certainly be reinforced by continuous engagement and sticking to the reflective practice. In stage two i.e. 'thinking reflectively,' Stanley believes that "most teachers first reaction to reflection is merely to evoke a classroom setting and explain what occurred and how they felt about this experience" (p. 686). In stage three, called 'using reflection,' he argued that "By the time teachers have gained awareness concerning what reflection is and how they can think reflectively, it can be used as a tool."

According to Stanley (1998, p. 687) "generally, acquiring any new skill needs a stage of experimentation concerning observing how reflection can unfold and when and with whom it can be done". In this stage, teachers seek to identify and figure out the actions that are consistent with their context. In stage four, called 'sustaining reflection,' Stanley points to various challenges teachers face while attempting to rehearse reflection. He talks about both critical and affective factors involving in reflective teaching that might impede teacher reflectivity. Lastly, in the fifth stage called 'practicing reflection,' Stanley explains about the practical dimensions of reflective teaching as an inevitable component of teacher reflectivity.

\subsection{Motivation}

Given various positive reasons for learning a second language, learners tend to perceive things in a different way. L2 teachers always seek to find ways to make their students interested in learning target language. To this end, they resort to many tricks and techniques (e.g. reward) to motivate the learners.

According to Ryan and Deci (2000, p. 54) "To be motivated means to be moved to do something. A person who feels no impetus or inspiration to act is thus characterized as unmotivated, whereas someone who is energized or activated toward an end is considered motivated". However, motivation is not considered as a monolithic concept. That is, there are different types of motivation influenced by various internal and external factors.

Along the same lines, there have been many motivation theories till now in the language learning field. Robert Gardner is thought to have established the most influential motivation theory (Dörnyei, 2001a). Gardner (1985, p. 10) suggests that motivation to acquire a foreign language is a mixture of factors including effort, desire and a positive attitude toward the language under consideration. 
A review of research shows that the term "motivation" has been defined in different ways. In Gardner's view (1985), to be motivated, the learner has to have something to look forward to, a reason related to a goal. Gardner (1985, p. 10) gave the following definition of motivation: "the combination of effort plus desire to achieve the goal of learning the language plus favorable attitudes toward learning the language". He argues that motivation involves answering the question "Why does an organism behave as it does? "According to Brown (1994, p. 152), "motivation is commonly thought of as an inner drive, impulse, emotion, or desire that moves one to a particular action".

In the context of L2 learning, this goal involves acquiring a foreign language. Learners need to be focused on and guided by a purpose i.e. learning second language. The learner's motivation for L2 may vary from achieving a sense of success, accomplish other's expectations or managing to be employed thanks to their command of the target language.

\subsection{Intrinsic/Extrinsic Motivation}

Dornyei (1998) proposed the dual concept of intrinsic and extrinsic motivation. Intrinsic motivation involves a type of motivation that drives the learner to participate in a task or an activity because he/she enjoys taking part in that. The intrinsically motivated learners engage in learning process as they seek to achieve a kind of goal which is both inspiring and satisfying to them.

In contrast, an extrinsically motivated individual conducts an activity or task to reach some instrumental end, such as getting higher score or receiving rewards. The extrinsically motivated individuals are encouraged by external motives to accomplish a goal. Avoiding the punishment can serve as an extrinsic motivation as well.

\subsection{Motivation and $L 2$ Learning}

Most language teachers believe that motivation is a key factor for success in language learning. There is no doubt that motivation is a potent force in language acquisition (Ellis, 1994). All effective language learning environments have an unquestionable dependence to the existence of intrinsic motivation in language learners.

Learning a second language appears to be a multi-dimensional ability that transcends linguistic and cognitive capacity of the student. As Kramsch (2001) argues, learning another language is not like learning math or other subjects. It tends to entail the linguistic and cognitive capacities of the learner as well as the social, historical, emotional, cultural, moral sense of self as a subject. Many factors have the potential to change the motivation level of the learners.

Dörnyei (1994a) conceptualized a general outline of L2 motivation. The outline includes three levels: the Language Level, the Learner Level, and the Learning Situation Level. Dörnyei (1994a) asserts that the Language Level is the most general level of the construct. The Language Level concentrates on orientations and motives related to various aspects of the L2, i.e., the culture that it puts across, the community in which it is spoken, and the possible benefits of proficiency in it. Together, these motives produce the basic learning goals. The Learner Level is the second level of this construct. It entails a complicated set of effects and cognitions which creates personal traits. There are two motivational components at this level, need for accomplishment and self-confidence. The third level is the Learning Situation Level, which is shaped by intrinsic and extrinsic motives and motivational conditions in relation to three areas. In this level, there are three principle types of motivational sources.

In Self-Determination Theory (SDT) Deci and Ryan (1985) made a distinction between various types of motivation on the basis of the different reasons or goals that produces an action. The most basic distinction is between intrinsic motivation, which refers to an action because it is inherently interesting or enjoyable, and extrinsic motivation, which refers to an action because it produces a separable result. More than three decades of research have demonstrated that the quality of experience and performance can produce different results when one is behaving for intrinsic versus extrinsic motives.

Krashen (2002) hypothesizes the 'affective filter' that includes various psychological factors, such as anxiety, motivation, and self-confidence, which can strongly improve or inhibit second language learning. An input rich learning condition is required where the learners are relaxed, motivated and self-confident in learning the second language successfully. Krashen (2002) believes that highly motivated students with self-confidence, a good self-image, and a low level of anxiety are well 
prepared in achieving second language acquisition. In Dornyei's view (2001), both external and internal factors that learners encounter during the process of language learning can be a source in labeling the motivation an evolving construct. There have been plenty of studies that prove the changeability of motivation.

\section{The STUdY}

The present study aimed at investigating the relationship between reflective teaching, willingness to communicate and intrinsic motivation of the Iranian EFL learners.

\subsection{Design of the Study}

The present study is correlational and quasi-experimental at the same time. As for the correlational part this study investigates the relationship between reflective teaching and willingness to communicate and intrinsic motivation.

\subsection{Participants}

There were three groups of participants in the present study:

- Twenty teachers: 20 teachers were chosen randomly from among 60 teachers teaching at different institutes in Tehran. There were 11 male and 9 female teachers. Since experience is an important factor in reflective teaching care was taken to select those teachers who had between 2 to 4 years of teaching experience. The age range of these teachers was from 22 to 34 .

- Some 240 advanced learners of English were the second group of participants in this study. They were all male learners and were chosen randomly from among 625 advanced learners studying at different English institutes in Tehran. Their age ranged from1 8 to 32 .

- Some 60 intermediate learners of English participated in the experimental part of the study. Initially, the number of participants were 90 male students studying at Intermediate level at a language school in Tehran. These subjects were studying in 6 classes which were chosen randomly from among 12 such classes. The range of their age was between 16 and 30. All of the participants were studying English at intermediate proficiency level. They were mainly high school and university students studying English for the purposes of finding better jobs or pursuing their studies abroad.

\subsection{Instruments}

Three instruments were used in the present study a discussion of which follows:

\subsubsection{Reflective Teaching Questionnaire}

The instrument used for measuring reflective teaching in this study was a reflective teaching questionnaire devised by Akbari, Behzadpour and Dadvand (2010). The questionnaire includes 42 items on a five-point Likert scale, consisting of five options of never, rarely, sometimes, often, and always, which has been devised based on six elements which are Practical, Cognitive, learner, Metacognitive, Critical, and Moral aspects of teaching. This questionnaire was chosen for the purposes of this study because it was developed for measuring teachers' reflection in the context of Iran and enjoys a high reliability of 0.90 as a measuring instrument for teacher reflectivity (Akbari et al., 2010).

\subsubsection{Intrinsic Motivation Questionnaire}

This questionnaire is based on the self-determination theory, comprising three sections related to intrinsic motivation. It has three sub parts which measures: (a) Intrinsic Motivation Knowledge, (b) Intrinsic Motivation Accomplishment and (c) Intrinsic Motivation Stimulation. IM-Knowledge is the motivation for learning an L2 for the feelings associated with exploring new ideas and developing knowledge. IM Accomplishment refers to the sensations related to the attempt to master a task or to achieve a goal. IM-Stimulation is related to motivation based simply on the sensations stimulated by performing the task, such as aesthetic appreciation, fun or excitement. The questionnaire consisted of thirty items with each ten items focusing on one of the above-mentioned constructs. Students were 
asked to show their agreement or disagreement with the items of the questionnaire in a five-point scale, ranging from strongly agree to strongly disagree ( $1=$ strongly disagree, $5=$ strongly agree).

\subsubsection{WTC Questionnaire}

This questionnaire was devised by MacIntyre et al (2001) to measure the learners' willingness to communicate. The questionnaire consists of 20 items on a Likert scale and the students were required to respond to the items in twenty minutes. They were asked to state how willing they were to initiate and continue a conversation in each situation (from 0 to 100\%).

\subsection{Procedures}

The procedure of the present study falls into two phases including the experimental phase and the correlational phase:

\subsubsection{The Experimental Phase}

Initially, two teachers -a reflective teacher and a non- reflective teacher were selected based on the results of reflective teaching questionnaire. The subjects of the experimental phase of the study were initially ninety adult intermediate EFL learners in one of the language academies of Tehran. They were studying in 6 classes chosen out of 10 such classes. Out of these 90 subjects 60 were selected based on the scores of PET administered to the subjects. To this end, only those participants whose scores fell under the normal curve that is one standard deviation above and below the mean were selected for the purposes of the current study. Following that, these sixty subjects were divided randomly into two groups i.e. an experimental and a control group.

The next stage unfolded as follows:

The experimental group was taught by the reflective teacher. During this class, the teacher drew upon the principles of reflective teaching offered by Kumaravadivelu (2006) who asserts that reflective action consists of many elements, involving an individual's willingness to be curious and assertive in order to increase self-awareness, self-knowledge, and new understandings of the world in which we live and work. The teacher analyzed the possible problems on the spot and addressed the issue accordingly. This required the researcher to explain the new approach to teaching beforehand so as to make the teacher ready for it. The teacher drew on both reflection in teaching and reflection on teaching. She took her time constantly to reflect on all lessons that she was required to teach. She wrote down her thoughts after each lesson to monitor her own development and the effectiveness of her teaching. For example, she reflected on the organization and presentation, as well as interaction among the learners while paying attention to the reactions, successes, and any obvious confusion that the students exhibited.

The control group was taught by the unreflective teacher. No tangible reflective actions were adopted by the teacher in this group. Finally, both groups sat for the PET exam again the results of which were used to explore the impact of reflective teaching on the proficiency level of the participants.

\subsubsection{The Correlational Phase}

Initially 20 teachers and 240 EFL advanced learners as described in section 3.2 were identified. Then the questionnaires were distributed among them. The reflective teaching questionnaire was distributed among the teachers and the WTC and intrinsic motivation questionnaires were given to the learners to be filled out. Before completing the questionnaires a brief explanation was given to the learners on how to fill it. To this end, comprehension and instruction check questions were employed to remove any ambiguities and assure that learners were on the right track. In order to obtain the proficiency scores of the participants a TOEFL was administered to the 240 advanced learners.

\section{RESUlts}

\subsection{Testing the Hypotheses}

To investigate the first three hypotheses of the study it deemed necessary to establish the normality assumption of different sets of data available. The normality assumption needs to be met since if this assumption is violated the data should be analyzed through non-parametric tests. On the other hand, if the data meet the normality assumption, it can be analyzed drawing on the parametric tests (Tabachnick\&Fidell, 2007). To this end, One-Sample Kolmogorov-Smirnov Test was run on the four data sets collected for the purposes of the study. Tables 4.1 and 4.2 display the descriptive statistics and One-Sample Kolmogorov-Smirnov Test results of the analysis, respectively. 
The Relationship between ReflectiveTeaching, Willingness to Communicate (WTC), and Intrinsic Motivation of Iranian Advanced Learners

Table1. Descriptive Statistics of the Reflective teaching, Willingness to Communicate, TOEFL and Intrinsic Motivation Scores

\begin{tabular}{|l|l|l|l|l|l|}
\hline & $\mathrm{N}$ & Mean & Std. Deviation & Minimum & Maximum \\
\hline Reflective Teaching Scores & 20 & 148.7000 & 22.40794 & 112.00 & 198.00 \\
\hline Willingness to Communicate Scores & 240 & 62.0208 & 12.05304 & 25.00 & 99.00 \\
\hline TOEFL Scores & 240 & 61.3292 & 10.13817 & 44.00 & 86.00 \\
\hline Intrinsic Motivation Scores & 240 & 86.9417 & 32.32570 & 25.00 & 147.00 \\
\hline
\end{tabular}

Table2. One-Sample Kolmogorov-Smirnov Test for establishing the Normality Assumption of the Four Data sets Collected in the Correlational Phase of the Study

\begin{tabular}{|c|c|c|c|c|c|}
\hline & & $\begin{array}{l}\text { Reflective } \\
\text { Teaching Scores }\end{array}$ & $\begin{array}{l}\text { Willingness to } \\
\text { Communicate } \\
\text { Scores }\end{array}$ & TOEFL Scores & $\begin{array}{l}\text { Intrinsic Motivation } \\
\text { Scores }\end{array}$ \\
\hline \multicolumn{2}{|l|}{$\mathrm{N}$} & 20 & 240 & 240 & 240 \\
\hline \multirow{2}{*}{$\begin{array}{l}\text { Normal } \\
\text { Parameters }\end{array}$} & Mean & 148.7000 & 62.0208 & 61.3292 & 86.9417 \\
\hline & Std. Deviation & 22.40794 & 12.05304 & 10.13817 & 32.32570 \\
\hline \multirow{3}{*}{$\begin{array}{l}\text { Most Extreme } \\
\text { Differences }\end{array}$} & Absolute & .105 & .164 & .162 & .269 \\
\hline & Positive & .105 & .164 & .162 & .269 \\
\hline & Negative & -.068 & -.086 & -.079 & -.090 \\
\hline \multicolumn{2}{|c|}{ Kolmogorov-Smirnov Z } & .469 & 2.541 & 2.510 & 4.166 \\
\hline \multicolumn{2}{|c|}{ Asymp. Sig. (2-tailed) } & .980 & .087 & .330 & .075 \\
\hline \multicolumn{6}{|c|}{ a. Test distribution is Normal. } \\
\hline \multicolumn{6}{|c|}{ b. Calculated from data. } \\
\hline
\end{tabular}

As it is noticed in Table 4.2 the significance levels are all above 0.05 indicating that all the data sets of the study in the correlational phase are normally distributed. Having established the normality assumption, the researcher employed the Pearson correlation Coefficient formula which is a parametric test to investigate the first three hypotheses formulated for the correlational phase of the study.

\subsubsection{Testing the First Hypotheses}

The first null hypothesis of the present study as there is no significant relationship between reflective teaching and WTC was investigated by running Pearson correlation coefficient on the scores of the WTC questionnaire and the reflective teaching scores. Table 4.3 demonstrates the results of this analysis.

Table3. Pearson Correlation Coefficient Results of the Reflective Teaching and WTC

\begin{tabular}{|c|c|c|}
\hline & & Reflective Teaching Scores \\
\hline \multirow{3}{*}{ Reflective Teaching Scores } & Pearson Correlation & 1 \\
\hline & Sig. (2-tailed) & \\
\hline & $\mathrm{N}$ & 20 \\
\hline \multirow{3}{*}{ Willingness to Communicate Scores } & Pearson Correlation & $.545^{* *}$ \\
\hline & Sig. (2-tailed) & .003 \\
\hline & $\mathrm{N}$ & 240 \\
\hline
\end{tabular}

*. Correlation is significant at the 0.05 level (2-tailed).

**. Correlation is significant at the 0.01 level (2-tailed).

As Table 4.3 shows there is a significant correlation between reflective teaching and WTC $(r=.545, \mathrm{p}$ $=.003<0.01)$. Therefore, it can be concluded that there is a positive and significant relationship between WTC and reflective teaching. Therefore, the first null hypothesis of the study is rejected.

\subsubsection{Testing the Second Hypotheses}

The second null hypothesis of the current study as there is no significant relationship between reflective teaching and intrinsic motivation was explored by running Pearson correlation coefficient on the scores of the intrinsic motivation questionnaire and the reflective teaching scores. Table 4.4 demonstrates the results of this analysis. 
Table4. Pearson Correlation Coefficient Results of the Reflective Teaching and Intrinsic Motivation

\begin{tabular}{|l|l|l|}
\hline \multicolumn{2}{|l|}{} & Reflective Teaching Scores \\
\hline \multirow{3}{*}{ Reflective Teaching Scores } & Pearson Correlation & 1 \\
\cline { 2 - 3 } & Sig. (2-tailed) & \\
\cline { 2 - 3 } Intrinsic Motivation Scores & $\mathrm{N}$ & 20 \\
\hline & Pearson Correlation & $.314^{*}$ \\
\cline { 2 - 3 } & Sig. (2-tailed) & .042 \\
\cline { 2 - 3 } & $\mathrm{N}$ & 240 \\
\hline
\end{tabular}

*. Correlation is significant at the 0.05 level (2-tailed).

**. Correlation is significant at the 0.01 level (2-tailed).

As it is shown in Table 4.4 a significant and positive correlation was found between reflective teaching and intrinsic motivation $(\mathrm{r}=.314, \mathrm{p}=.042<.05)$. Thus, the second null hypothesis of the study is rejected as well.

The results of data analysis in this study indicated that:

- There is a positive and significant relationship between reflective teaching and WTC.

- There is a positive and significant relationship between reflective teaching and proficiency test scores.

\section{DISCUSSION AND CONCLUSION}

The present study sought to explore the relationship between reflective teaching, willingness to communicate and intrinsic motivation of the Iranian EFL learners. As motivation is one of the most important concepts in psychology and language education, which is commonly used to explain learners' success and failure in learning (Dörnyei, 2009), it cannot be neglected as an important element related to critical thinking. The current study and its findings are in keeping with Littlejohn (1997, cited in Benson \&Voller, 1997) who contended that the role of the curriculum and classroom practice in promoting WTC and motivation should be taken more seriously. In the current study it was revealed that reflective teaching is effective in enhancing the proficiency level of the participants. One of the possible explanations for this result could be the fact that when teachers are involved in reflective practice they pay more attention to the process of their teaching and as a result can help students learn more independently and thoughtfully. Put it other way, when a teacher is thinking about her own practice in the classroom and considers reflection as an important aspect of her job, she will inevitably transfer this way of thinking and doing things to the learners which in turn will result in improving learner autonomy and consequently better proficiency gains.

The findings also give support for the arguments of Benson (2000), Brown (1994), Dickinson (1995), Holec (1981) and Little woods (1999), who have stated that intrinsic motivation will be fostered if we give the second language learners an amount of freedom to the extent that they can think critically for their own course of learning. In other words, in the current study the improvement in proficiency level due to reflective teaching practiced, might have in one way or another impacted the motivation level of the learners' positively. According to Ryan and Deci (2000), intrinsic motivation stems from the organism's need to be competent and self-determining. Perception of competence and perception of control are apparently distinct but not easily separated. If a learner perceives himself as being a highly competent thinker in a learning situation, then the opportunities to take control of that situation will be meaningful to him. Moreover, in order to experience a feeling of competence, it is necessary to feel responsible for the actions and outcomes that demonstrate competence (Ryan \&Deci, 2000).

Another possible explanation for the relationship between intrinsic motivation and reflective teaching in this study could be found in what Dornyei (2001, p. 26) mentions as "the best motivational intervention is simply to improve the quality of our teaching". Reflective teaching practice can be, therefore, seen as a factor which has increased the quality of teaching and subsequently the intrinsic motivation level of the learners and finally their proficiency gains.

Evidently, one of the main factors which teachers need to take into account while dealing with learners in the language teaching enterprise is motivation. Most language teachers believe that motivation is a key factor for success in language learning. There is no doubt that motivation is a potent force in language acquisition (Ellis, 1994). There have been plenty of studies that prove the 
changeability of motivation. As an important factor, the way teachers teach can contribute to motivation according to the results of the current study. That is reflective teaching has brought about a change in the motivation level of the participants.

According to the findings of this study, using reflective teaching is effective on proficiency level, which simply means teachers should try to adopt a reflective way of practice so as to help the learners improve their intrinsic motivation and consequently their gains in language learning.

Teacher trainers may devise and plan courses through which teacher trainees become familiar with how to adopt a reflective way of teaching that best helps student improve their intrinsic motivation and WTC.

Last but not least, there could be some sessions where both teachers and students participate so they get familiar with what reflective teaching and intrinsic motivation as well as WTC and proficiency are and how they work together.

\section{REFERENCES}

Adams, R. (2003). L2 output, reformulation and noticing: Implications for IL development. Language Teaching Research, 7(3),347-376.

Akbari, R. (2007). Reflections on reflection: A critical appraisal of reflective practices in L2 Teacher Education. System, 35(2), 192-207.

Akbari, R., Behzadpoor, F., \& Dadvand, B. (2010).Development of English language teaching reflection inventory. System, 38(2), 211-227.

Al-Issa. (2010). Training English language student teachers to become reflective teachers, Australian Journal of Teacher Education. 35(1), 41-64.

Baker, J. \&Westrup, H. (2003). Essential speaking skills: A handbook for English language teachers. London: Continuum.

Behzadpour, F. (2007). Developing a measuring instrument for reflective teaching. Unpublished master thesis, Tarbiat Modares University, Tehran, Iran.

Benware, C., \&Deci, E. L. (1984). Quality of learning with an active versus passive motivational set. American Educational Research Journal, 21(4), 755-765.

Bolton, G. (2010). Reflective practice, writing and professional development (3rd Ed.). California: SAGE Publications.

Boody, R. M. (2008). Teacher reflection as teacher change, and teacher change as moral response. Education, 128(3), 498-506.

Boud, D., Keogh, R. \& Walker, D. (1985). Promoting reflection in learning: A model. In: D. Boud, R. Keogh \& D. Walker. (Eds.), Reflection: Turning experience into learning. (pp.18-40). London: Kogan.

Bransford, J. D., Sherwood, R. D., \& Sturdevant, T. (1987). Teaching thinking and problem solving. In J. B. Baron \& R. J. Sternberg (Eds.), Teaching thinking skills: Theory and practice (pp. 120134).New York: W. H. Freeman and Company.

Briere, E. J. (1972). Are we really measuring proficiency with our foreign language tests? In H. B. Allen \& R. N. Campbell (eds.), Teaching English as a second languages: A book of readings ( $2^{\text {nd }}$ ed.) (pp. 109-122). New York: McGraw-Hill Book Company.

Brookfield, S. (1985).Self-directed learning: A critical review of research. In S. Brookfield (Ed.). Selfdirected learning: from theory to Practice (pp. 5-16).San Francisco, CA: Jossey-Bass.

Brown, D. (2000). Principles of language learning and teaching.(4th ed.). New York: Addison Wesley Longman

Brown, H. (2001). Teaching by principles: An interactive approach to language pedagogy (3rd). White Plains, NY: Longman.

Brown, H. D. (1990). M \&Ms for language classrooms? Another look at motivation. In J. E.Alatis (ed.), Georgetown University round table on language and linguistics (pp. 383-93). Oxford: Oxford University Press.

Brown, H. D. (1994). Teaching by principles. Englewood Cliffs, NJ: Prentice Hall. 
Burns, A and Joyce, H. (1997).Focus on speaking. Sydney: National center for English language teaching and research.

Burns, A. (1998). Teaching speaking. Annual Review of Applied Linguistics, 18(3), 102-123.

Bygate, M. (1987). Speaking. Oxford: Oxford University Press.

Bygate, M. (1998). Theoretical perspectives on speaking. Annual Review of Applied Linguistics, 18, (1), 20-42.

Canning, C. (1991). What teachers say about reflection? Educational Leadership, 48(6), 18-21.

Chang, H. H. (2005). The relationship between extrinsic/intrinsic motivation and language learning strategies among college students of English in Taiwan. Unpublished master thesis. Ming Chuan University, China.

Choy ET. al. (2012). Reflective thinking and teaching practices: a precursor for incorporating critical thinking into the classroom? International Journal of Instruction, 10(1), 15-19.

Clarke, R., Croft, P. (1998).Critical reading for the reflective practitioner. Butterworth Heineman, Oxford.

Clément, R. (1978). Second language proficiency and acculturation: An investigation of the effects of language status and individual characteristics. Journal of Language \&Social Psychology, 5(2), 271-290.

Clément, R., Gardner, R. C., \& Sym the, P. C. (1977). Motivational variables in second language acquisition: A study of Franco phones learning English. Canadian Journal of Behavioral Science, 9 (1), 123-133.

Clément, R., Gardner, R. C., \&Sym the, P. C. (1980).Social and individual factors in second language acquisition. Canadian Journal of Behavioral Science, 12(2), 293-302.

Collins, K. M. \&Onwuegbuzie, A. J. (2000, March). Relationship between critical thinking and performance in research methodology courses. Paper presented at the annual conference of Motivation: Reopening the research agenda.

Cornbleet, S. \& Carter, R. (2001). The Language of speech and writing. London: Rutledge.

Courtney, M. (1996). Talking to learn: Selecting and using group oral tasks. ELT Journal. 5(4), 318325 .

Day, D. V. (2000). Leadership development: A review in context. The Leadership Quarterly, 11(4), 581-613.

Deci I E. L., Nezlek, J., \& Sheinman, L. (1981). Characteristics of the rewarder and intrinsic motivation of the rewardee. Journal of Personality and Social Psychology, 40(1), 1-10.

Deci, E. L. (1971). Effects of externally mediated rewards on intrinsic motivation.Journal of Personality and Social Psychology, 18(1), 105-115.

Deci, E. L., \& Ryan, R. M. (1985). Intrinsic motivation and self: Determination in human behavior. New York: Dublin Press.

Deci, E. L., Connell, J. P., \& Ryan, R. M. (1989). Self-determination in a work organization. Journal of Applied Psychology, 74(4), 580-590.

Deci, E. L., Eghrari, H., Patrick, B. C., \& Leone, D. R. (1991). Facilitating internalization: The selfdetermination theory perspective. Unpublished manuscript, University of Rochester, Rochester, NY.

Deci, E. L., Koestelr, R., \& Ryan, R. M. (1999). A nieta-anualytic review of experiments examining the effects of extrinsic rewards on intrinsic motivation. Psychological bulletin.

Dewey, J. (1933). How we think: A restatement of the relation of reflective thinking to the educative process. New York D. C: Heath and company.

Dewey, J. (1933). How we think: A restatement of the relation of reflective thinking to the educative process. New York D. C: Heath and company.

Dickinson, L. (1995). Autonomy and motivation: A literature review. System, 15(1), 131-157.

Dörnyei, Z. (1998). Conceptualizing motivation in foreign language learning, Language learning, 40(1), 46-78.

Dornyei Z, Csizar K. (1998). Ten Commandments for motivating language learners: Results of an empirical Study. Language Teaching Research, 23(2), 203-229. 
The Relationship between ReflectiveTeaching, Willingness to Communicate (WTC), and Intrinsic Motivation of Iranian Advanced Learners

Dörnyei, Z. (1994a). Motivation and motivating in the foreign language classroom. The Modern Language Journal, 78(2), 273-284.

Dörnyei, Z. (1998). Motivation in second and foreign language learning. Language teaching,31(1), $117-135$.

Dörnyei, Z. (2001). New themes and approaches in L2 motivation research. Annual Review of Applied Linguistics, 21(1), 43-59.

Dörnyei, Z. (2001). Teaching and researching motivation. Harlow: Pearson.

Dörnyei, Z. (2003). Questionnaires in second language research: Construction, administration, and processing. Mahwah, NJ: Erlbaum.

Eckard, R. \& Kearny, M. (1981). Teaching conversational skills in ESL. Washington: Center of applied linguistics.

Ellis, R. (1994). Activities and procedures for teacher preparation. In J. C. Richards \& D. Nunan (eds). Second language teacher education(pp. 26-36).Cambridge, UK: Cambridge University Press.

Ellis, R. (1994). The study of second language acquisition. Oxford: Oxford University press.

Ellis, R. (2003). Task-based language learning and teaching. Oxford: Oxford University Press.

Facione, P., Facione, N. C., Blohm, S. W., Howard, K., \& Giancarlo, C. A. F. (1998). California Critical Thinking Skills Test. Millbrae, CA: California Academic Press.

Farrell, T. (1999). Reflective practice in an EFL teacher development group. System, 27(2), 157-172.

Farrell, T. (2004). Reflective practice in action: 80 reflection breaks for busy teachers. Thousand Oaks, California: Corwin Press, Sage Publication Company.

Finch, A. (1999).The task-based classroom in practice. A paper presented at PAC2 conference.

Finch, A. E. \& Hyun, T. D. (2000).Tell Me More! Seoul: Hakmunsa Press.

Florez, M. A. (1999).Improving adult English language learners' speaking skills. ERIC Digest. Michigan: The University of Michigan Press.

Foster, P., Tonkeyn, A. \& Wigglesworth, G. (2000). Measuring spoken language: A unit for all reasons. Applied Linguistics, 21(3), 354-375.

Gardner, H. (1983). Review of the book. Theory of multiple intelligences. Early childhood today, 20(3), 68-78.

Gardner, R. C. (1985). Social psychology and second language learning: The roles of attitudes and motivation. London: Edward Arnold.

Gardner, R. C., \& Lambert, W. E. (1959). Motivational variables in second language acquisition. Canadian Journal of Psychology, 13(4), 266-272.

Gardner, R. C., \& MacIntyre, P. D. (1992).A student's contribution to second language learning. Part I: Cognitive variables. Language Teaching, 25(2), 211-220.

Graves, K. (2002). Developing a reflective practice through disciplined collaboration. The Language Teacher, 26(1), 19-21.

Green, S. (2000). New perspectives on teaching and learning modern languages. Toronto: Multilingual Matters Ltd

Grolnick, W. S., Deci, E. L., \& Ryan, R. M. (1997). Internalization within the family: The selfdetermination perspective. In J. E. Grusec\& L. Kuczynski (Eds.), Parenting and children's internalization of values: A handbook of contemporary theory (pp. 135-161). New York: Wiley.

Gower, R. Diane, P. \& Walters, S (2005). Teaching practice a handbook for teachers in training. Oxford: Macmillan Education.

Gower, R. and S. Walters. (1983). A teaching practice handbook. London: Heinemann.

Harackiewicz, J. (1979). The effects of reward contingency and performance feedback on intrinsic motivation. Journal of Personality and Social Psychology, 37(10),1352-1363.

Harmer, J. (1983).The practice of English language teaching. London: Longman.

Harter, S. (1981). A new self-report scale of intrinsic versus extrinsic orientation in the classroom room: Motivational and informational components. Developmental psychology, 17(4),300-312. 
Hedge. (2000). Oxford handbooks for language teachers: Oxford University Press.

Hedge, T. (2000). Teaching and learning in the language classroom. Oxford: Oxford University Press.

Horwitz, E. K., Horwitz, M. B. \& Cope, J. (1986).Foreign language classroom anxiety. Modern Language Journal, 70(1), 125-132.

HosseiniFatemi. A, Elahi Shirvan,M. Rezvani,Y. (2011). The effect of teachers' Self-refection on EFL Learners' writing achievement. Cross-cultural Communication,7(3), 175-181.

Howarth, P. (2001). Process Speaking. Preparing to Repeat Yourself. MET, 10(1), 39-44.

Hughes, R. (2002). Teaching and researching speaking. Warlow: Longman.

Inozu, J. (2011). Beliefs about foreign language learning among students training to teach English as a foreign language social behaviour and personality. Society for Personality Research, 39(5), 645654.

Javadi, F. \&Khatib, M. (2014).On the relationship between reflective teaching and teachers' burnout, International Journal of Research Studies in Language Learning, 3(4), 368-374.

Jay, J. K., \& Johnson, K. L. (2002). Capturing complexity: a typology of reflective practice for teacher education. Teaching and Teacher Education, 18(1), 73-85.

Jenkins, E. K. (1998). The significant role of critical thinking in predicting auditing students' performance. Journal of Education for Business, 73(5), 274 -279.

Kasper, G. (2001). Four perspectives on L2 pragmatic development. Applied Linguistics, 22(4), 502530.

Kimura Y, Nakata Y, Okumora T. (1997). Language learning motivation of EFL learners in Japan: A cross-sectional analysis of various Learning milieus. JALT Journal,6(1),47-66

Koch, A. S. \& Terrell, T. D. (1991).Affective reactions of foreign language students to natural approach activities and teaching techniques. In E. K. Horwtiz \& D. J. Young (Eds.), Language anxiety: From theory and research to classroom implications (pp. 109-126). Englewood cliffs, NJ: Prentice Hall.

Kramsch, C. (2001). Language and culture. Oxford: Oxford University Press.

Kumaravadivelu, B. (2006). Understanding language teaching: From method to post method. New Jersey: Lawrence Erlbaum.

Lee, J. (2000). Tasks and communicating in language classroom. New York: McGraw- Hill Higher Education.

Legutke, M \& Thomas. H. (1991).Process and experience in the language classroom. Harlow: Longman.

Leitch, R. \& Day, C. (2000). Action research and reflective practice: Towards a holistic view. Educational Action Research, 8(1), 179 - 193.

Lepper, M. R., Greene, D., \& Nisbett, R. E. (1973). Undermining children's intrinsic interest with extrinsic rewards: A test of the "over justification" hypothesis. Journal of Personality and Social Psychology, 28(1), 129-137.

Logan, G. E. (1980). Individualized foreign languages instruction: American patterns for accommodating learner differences in the classroom. In H. B. Altman \& C. V. James (Eds.). Foreign language teaching: Meeting individual needs (pp. 94-110).Oxford: Pergamumpress.

Long, M. (1996). The role of linguistic environment in second language acquisition. In W. Ritchie and T. Bhatia (Eds.).Handbook of second language acquisition, (pp. 413-468). Sand Diego, CA: Academic Press.

Luoma, S. (2004).Assessing speaking. Cambridge: Cambridge University Press.

Ma,L. \&Ren, S. (2011). Reflective teaching and professional development of young college English teachers-from the perspective of constructivism, Theory and Practice in Language Studies, l(2), 153-156.

MacIntyre, K. MacMaster and S. C. Baker, (2001). The convergence of multiple models of motivation for second language learning: London: Routledge.

MacIntyre, P. D. \& Gardner, R. C. (1991). Methods and results in the study of anxiety in language learning: A review of the literature. Language Learning, 41(1), 85-117. 
The Relationship between ReflectiveTeaching, Willingness to Communicate (WTC), and Intrinsic Motivation of Iranian Advanced Learners

MacIntyre, P. D. (1994). Variables underlying willingness to communicate: A causal analysis. Communication Research Reports, 11(1),135-142.

MacIntyre, P., \&Charos, C. (1996). Personality, attitudes, and affect as predictors of second language communication. Journal of Language and Social Psychology, 15(1),3-26.

MacIntyre, P., Clement, R., Dornyei, Z., \& Noels, K. (2002). Conceptualizing willingness to communicate in a L2: A situational model of L2 confidence and affiliation. The Modern Language Journal, 82(6), 545-562.

Mackey, A., Gass, S., \& McDonough, K. (2000). How do learners perceive international Feedback? Studies in Second Language Acquisition, 22(4), 471-497.

Martin, M. W. \&Wedman, J. M. (1988). Identifying student teachers' routine and reflective thoughts through journal analysis. Educational and Psychological Research, 8(4), 279-289.

Maslach, C., Schaufeli, W. B., \&Leiter, M. P. (2001). Job burnout. Annual Review of Psychology, 52(4), 397-422

McCarthy, M. \& Carter, R. (2001). Designing the discourse syllabus. In D. Hall and A. Hewing's (Eds.).Innovation in English language teaching,(pp. 55- 63). London: Routledge.

Mccollum, S. (1997).Insights into the Process of guiding refection during an early field experience of pre-service teachers. Unpublished doctorate dissertation. Virginia polytechnic institute and state University, Virginia.

McCroskey, J. C. \& Baer, J. E. (1985, February).Willingness to communicate: The construct and its measurement. Paper presented at the annual convention of the speech communication association, Denver, CO.

McCroskey, J. C. \& Richmond, V. P. (1990).Willingness to communicate: A cognitive view. In M. Booth-Butterfield (Ed.), Communication, cognition, and anxiety. Newbury Park, CA: Sage.

McCroskey, J. C. (1992). Reliability and validity of the willingness to communicate scale. Communication Quarterly, 40(1), 16-25.

McDonough, J., and Shaw, C. (2003). Materials and methods in ELT. 2nd ed. Maine: Blackwell Publishing.

Miller, L. (2001). A Speaking lesson .How to make the course book more interesting. MET, 10, (1), 25-29.

Noels KA. (2001). Learning Spanish as a second language. : Learners' Orientations and perceptions of their teachers' communication styles. Language Learning, 51(2), 107-144.

Noels, K. A., Pelletier, L. G., \&Vallerand, R. J. (2000). Why are you learning a second language? Motivational orientations and self-determination theory. Language learning, 50(1), 57-85.

Nunan, D. (1989). Designing tasks for the communicative classroom. New York: Cambridge University Press.

O’Donnell, A. M., J. Reeve \& J. K. Smith. (2012). Educational psychology. Reflection for Action. Hoboken, NJ: John Wiley \& Sons.

Osterman, K. F., \& Kottkamp, R. B., (2004). Reflective practice for educators: Improving schooling through professional development $\left(2^{\text {nd }}\right.$. Ed.) Thousand Oaks. CA, Corwin.

Parrott, M. (1993). Tasks for language teachers: A resource book for training and development. Cambridge: Cambridge University Press.

PintricH, P. L. \& Schunk, D. H. (1996).Motivation in education: theory, research, and applications. Englewood Cliffs, NJ: Prentice Hall.

Pollard, A. Anderson, J., Maddock, M., Swaffield, S., Warin, J and Warwick, P. (2008).Reflective teaching. London, Continuum.

Pourhosein Gilakjani, A., Leong, L. \& Sabouri, N. (2012). A Study on the role of motivation in foreign language learning and teaching, International Journal of Modern Education and Computer Science, 7(1), 9-16.

Ragan, L. C. (1998).Good teaching is good teaching: An emerging set of guiding principles and practices in design and development of distance education. New York: Addison Wesley Longman. 
Rahman, S., MohdJelas, Z., \& Osman, K. (1999).The Conception, perception and the practice of reflective thinking among student teachers. (Report no. G6/99). Bangi: Fakulti Pendidikan, University Kebangsaan Malaysia.

Rezaeyan, M. \& Nikoopour, J. (2013). The relationship between reflectivity of foreign language teachers with Iranian students' achievement. Journal of Language Sciences \& Linguistics, 1(1), 9-20.

Richards, J. C., \& Lockhart, C. (1996).Reflective teaching in second language classrooms. Cambridge: Cambridge University Press.

Richards. J. C., \& Schmidt, R. (2010). Dictionary of language teaching and applied linguistics $\left(5^{\text {th }}\right.$ Ed.).USA: Longman.

Richardson, V. (1990). The evolution of reflective teaching and teacher education. In R. T. Clift, W. R. Houston, \& M. C. Pugach, (Eds.), Encouraging reflective practice in education (pp. 129-145). New York: Teachers College Press.

Roberts, J. (1998). Language teacher education. London: Arnold.

Rose, M. (2007). The reflective practitioner. European center for modern languages. Retrieved May 15, 2007 from http://www.ecml.at/html/quality/english/cotinum/self_assessment/teachers/MR_ reflective\%20practitioner html.

Rudd, R., Baker, M., \& Hoover, T. (2000).Undergraduate agriculture student learning styles and critical thinking abilities: Is there a relationship? Journal of Agricultural Education, 41(3), 2-12.

Ryan and Deci. (2000). Intrinsic and extrinsic motivations: Classic definitions and new directions. Contemporary Educational Psychology, 25(1), 54-67.

Ryan, R. M. (1982). Control and information in the intrapersonal sphere: An extension of cognitive evaluation theory. Journal of Personality and Social Psychology, 43(4), 450-461.

Ryan, R. M., \& Grolnick, W. S. (1986). Origins and pawns in the classroom: Self-report and projective assessments of individual differences in children's perceptions. Journal of Personality and Social Psychology, 50(5), 550-558.

Sadighi F, \& Zarafshan M. (2006).Effects of attitude and motivation on the use of language learning strategies by Iranian EFL University students. Journal of Social Sciences and Humanities of Shiraz University, 23(1), 71-80.

Sayer, P. (2005). An intensive approach to building conversational skills.ELT Journal. 59(1), 27-36.

Schon, D. (1983). The reflective practitioner: How professionals think in action. New York: Basic Books.

Schon, D. A. (1983).The reflective practitioner: How professionals think in action. London: Temple Smith.

Schon, D. A. (1987).Educating the reflective practitioner: Towards a new design for teaching and learning in the profession. San Francisco: Jossey-Bass.

Slimani-Rolls, A. (2005). Rethinking task-based language learning: What we can learn from the learners. Language Teaching Research, 9(2),195-218.

Stanley, C. (1998). A framework for teacher reflectivity. TESOL quarterly, 32(5), 584-591.

Swain, M.\&Lapkin, S. (2000). Task-based second language learning: The uses of the first language. Language Teaching Research, 4(3), 251-274.

Swain, M. (1985). Communicative competence: Some roles of comprehensible input and comprehensible output in its development. In S. Gass\& C. Madden (Eds.).Input in second language acquisition(pp. 235-253). Rowley, Mass: Newbury house.

Swain, M. (2000). The output hypothesis and beyond: Mediating acquisition through collaborative dialogue. In J. P. Lantolf (Ed.), sociocultural theory and second language learning (pp. 97-114). Oxford: Oxford University Press.

Swain, M., \&Lapkin, S. (2002). Talking it through: Two French immersion learners' response to reformulation. International Journal of Educational Research, 37(3), 285-304.

Sze, P. (1999). Reflective teaching in second language teacher education: An overview. Educational Research Journal,14(1), 23-32. 
The Relationship between ReflectiveTeaching, Willingness to Communicate (WTC), and Intrinsic Motivation of Iranian Advanced Learners

Tabachnick, B. G., \& Fidell, L. S. (2007). Using multivariate statistics. Boston, MA: Pearson Education, Inc.

Torres, R. M., \& Cano, J. (1995a). Critical thinking as influenced by learning style. Journal of Agricultural Education, 36(4), 55-62.

Tsangaridou, N., \&O'sullivan, M. (1994). Using pedagogical reflective strategies to enhance reflection among Pre-service physical education teachers. Journal of Teaching in physical Education, 14(1), 13-33.

Thornbury S. (2005): How to teach speaking. Pearson: Longman

Ur, P. (1991). A course in Teaching English: practice and theory. Cambridge: Cambridge University Press,

Ushida, E., (2005).The role of Students' attitudes and motivation in second language learning in online language courses. Paper presented at CALICO 2005, Orlando, FL.

Valencia, J. A. (2009). An exploration of Colombian EFL teachers' knowledge base through Teacher's' reflection. Languages \& Encino, 12(1), 73-108.

Vallerand, R. J. (1997). Toward a hierarchical model of intrinsic and extrinsic motivation, In M. P. Zanna, (ed.): Advances in experimental social psychology(pp. 271-360). San Diego, CA: Academic Press.

Vygotsky, L. S. (1978). Mind in society: The development of higher psychological processes. Cambridge, MA: Harvard University Press.

Wajnryb, R. (1992). Classroom observation tasks. Cambridge: Cambridge University Press.

Wallace, M. (1996). Structured reflection: The role of the professional project. In D. Freeman \& J. C. Richards (Eds.), Teacher learning in language teaching (pp. 281-294). Cambridge: Cambridge University Press.

Wenden, A. L. (1991a). Learner strategies in language learning. Englewood cliffs, NJ: Prentice Hall.

White, R. (1959). Motivation reconsidered: The concept of competence. Psychological Review, 66(3), 297-333.

Widdowson, H. (1998). Skills, abilities, and contexts of reality. Annual Review of Applied Linguistics, 18(3), 323-33.

Willis, J. (1996). A framework for task-based learning. Harlow: Longman.

Xiaoxiao, L., \& Yan, L. (2010). A case study of dynamic assessment in EFL process writing. Chinese Journal of Applied Linguistics, 33(1), 24-40.

Yildirim, A. G. O. (2008). Vygotsky's sociocultural theory and dynamic assessment in language learning. Anadolu University Journal of social sciences, 8(1), 301-308.

Zeichner, K. M., \& Liston, D. P. (1996). Reflective teaching: An introduction. New Jersey: Lawrence Erlbaum Associates, Inc., Publishers.

\section{AUTHOR'S BIOGRAPHY}

Mohammad Zohrabi, was born in Tabriz, Iran in 1969. He is an assistant professor and has taught various courses both at undergraduate and graduate level at the University of Tabriz, Iran. He has published various articles in international journals and produced five books. His research interests include: discourse analysis, genre analysis, task-based language learning and teaching, program evaluation, material writing and evaluation, first and second language acquisition, teaching reading and writing skills, and English for academic and specific purposes.

Maryam Yousefi Isakan, was born in Tehran, Iran, in 1985. She received the Master degree in English Language Teaching from the University of Tabriz (UT), Iran, in 2016. Her special research interests include English language teaching techniques, reflective teaching and willingness to communicate, reflective teaching and motivation and translation. Currently, she works as a teacher at several private English language institutes. 